\title{
Fostering an integrated tourism education curriculum in Lesotho: A community participation approach
}

\section{Boitumelo Moreeng}

School of Education, Department of Education Studies, Sol Plaatje University, Kimberley, South Africa

Boitumelo.moreeng@spu.ac.za

https://orcid.org/0000-0002-3644-3140

\section{Mzamane Nhlapo}

Khukhune High School, Khukhune Village, Butha-Buthe 452, Lesotho

Mzamanenhlapo@yahoo.com

https://orcid.org/0000-0002-7993-2219

\section{Motsélisi Lilian Malebese}

Faculty of Education, Community Based Research (COMBER), North West University, Potchefstroom, South Africa

33666679@nwu.ac.za

https://orcid.org/0000-0003-0449-6229

(Received: 16 September 2019; accepted: 5 March 2020)

\section{Abstract}

In this paper we report on ways of fostering an integrated tourism curriculum by employing a community participation approach. As a vocational subject, tourism is intended to provide learners with practical and entrepreneurial skills. However, tourism is taught largely as a theory-based subject, and this is not in accordance with the demands of an integrated curriculum that aims to strengthen survival skills and self-reliance. We used a community participation approach to show how much cultural wealth learners and their communities can bring to the learning environment, and the value that this might hold for enhancing their academic performance and empowering them with vital life skills. We employed participatory action research as the methodology to generate our data, and content analysis to analyse and interpret it. We found that the tourism curriculum could be fostered through the learners' improved understanding of tourism as a vocational subject, collaboration among the stakeholders, and if resources were available and were used properly.

Keywords: integrated curriculum, tourism, community participation, participatory action research 


\section{Introduction}

In this article, we report on ways to foster an integrated tourism curriculum in Lesotho employing a community participation approach (CPA). In 2009, Lesotho underwent a process of curriculum change that resulted in the adoption of an integrated curriculum. This move was seen as a significant departure in how to integrate theory, skills, and attitudes (Brauer \& Ferguson, 2015; Raselimo \& Mahao, 2015). An integrated curriculum facilitates the transfer of learning that includes the carry-over of knowledge, skills, habits, and attitudes between and among subjects as a result of social interaction between teachers and learners from different disciplines and backgrounds (Graven \& Schafer, 2013). The interaction between teachers makes it possible to share mutually beneficial information. The core of the integrated curriculum addresses the active construction of knowledge by learners from many perspectives (Park, 2008), because it is learner-centred. An integrated curriculum brings to the fore different teachers and diverse disciplines and forges team spirit among them. This allows for the addressing of common themes and topics, depending on their interrelatedness (Park, 2008) by taking advantage of the mental capacity to make better connections across different contexts (Lake, 1994). According to the Lesotho Ministry of Education and Training (MoET), every opportunity to relate theory to the outside world should be exploited. This plays a role in using education to emancipate learners from poverty through methods and approaches that encourage creativity, productivity, and entrepreneurship (MoET, 2009). The implication for tourism education is, therefore, that it should be taught from an interactive and learner-centred approach, with more emphasis on the vocational aspects, so as to equip learners with creative, practical, productive, and entrepreneurial skills (Ezeh \& Ekemenzie, 2015), so that they achieve self-reliance through solving real-life problems as Mahlomaholo (2010) has pointed out.

\section{Tourism as a school subject}

Tourism was introduced as a fully-fledged subject in Lesotho in 2011, as stipulated by the 2009 integrated curriculum (MoET, 2009) that supports the fostering of self-reliance through the development of practical and entrepreneurial skills for self-employment by using interactive cross-curricular means to produce knowledge (see Brauer \& Ferguson, 2015) with a greater vocational focus since this equips learners with creative, practical, productive, and entrepreneurial skills to achieve self-reliance (Ezeh \& Ekemenzie, 2015; MoET, 2009; Omede, 2012).

In this study, we agree with Chere-Masopha (2007) that tourism is said to be an enterprise that offers the immediate practical benefits of improving the lives of learners. Offering tourism education in schools and in institutions of higher learning is based on the fact that tourism activities contribute significantly to the economy of a country as Lovrentjev (2015) and Petersen (2015) have noted, and that tourism can create employment opportunities. This means that tourism undoubtedly plays a considerable role in national development (Lovrentjev, 2015; Sarkodie \& Adom, 2015). In South Africa, tourism can help to redress some of the injustices of the past as Dube (2014) has reminded us. If the tourism industry is 
to thrive and contribute to economic growth and national development, it depends on this subject being available to learners; this makes our study an important one.

The introduction of tourism as a school subject has involved challenges that have affected its effective implementation. There seems to have been confusion about the nature of the subject and this information was not communicated well enough to the different stakeholders to ensure common understanding. Dube (2014) suggested that tourism is viewed as being of low status in South Africa since it is not designated in the list of subjects for university entrance. As a result, schools do not get the necessary support and resources to ensure proper implementation of this subject (Shankar, 2014). Community involvement in tourism education could also present a challenge, even though it is an important component of the subject, because vocational subjects require a variety of resources (Akyeampong, 2002). Nkumane (2008) and Tsayang (1998) have found there to be a lack of participation by communities in tourism education, the latter in Botswana, because communities feared crossing professional boundaries, and because curriculum areas for community participation have never been clarified. Furthermore, stakeholders, such as teachers, school managers, and parents have to undergo continual training to improve their understanding of tourism in an integrated curriculum (Daly, Brown, \& McGowan, 2012; Malik \& Malik, 2011).

\section{Research problem}

Tourism was introduced in high schools as a vocational subject to expose learners to a handson and work-related curriculum that would enable them to confront head-on the challenges of poverty and unemployment. Unfortunately, it has been noted that the teachers continue to focus on only the academic textbook objectives, without addressing the vocational components of the subject (Akyeampong, 2002). These objectives are theoretically biased, and do not relate to the integrated curriculum policy document that is vocationally focused, and that emphasises creativity, practical production, and entrepreneurial skills for alleviating poverty along with striving to achieve self-reliance (MoET, 2009). Most importantly, teaching approaches preclude community members and other stakeholders from entering the classroom to participate in the teaching and learning process.

In this paper we attempt to eliminate the gap between what is currently taught (the theoretical content for the sole purpose of passing examinations) and the expectations of an integrated curriculum (the acquisition of productive and entrepreneurial skills that would equip learners with the means to overcome poverty and unemployment, and strive to achieve self-reliance). We raise and examine the question: How can we foster an integrated tourism curriculum in Lesotho using CPA?

\section{Conceptual framework}

We used CPA in this study to engage ordinary community members as participants in the classroom in order to strengthen the learners' understanding of tourism primarily for practical purposes rather than academic, and to encourage them to apply their newly acquired 
knowledge and skills to their daily lives. According to Dorsner (2004), community participation emerged as a vehicle for the development of poor people in the 1990s, after it became cumbersome for governments and international agencies to provide the necessary support to them. CPA is used to enhance efficiency, accountability, transparency, ownership, and empowerment of people. Its purpose here was to assist communities to rise up and develop themselves by being active participants in a tourism-related project as suggested by Shepherd (1998) in a different context. CPA is made up of two distinct words - community and participation. Community refers to a group of people who live together, who recognise one another and identify themselves in the first person plural, "we", and who are held together by custom and solidarity. A community is a local social system that embraces social, economic, and political dimensions (Inglis \& Aers, 2008). In general, a community enjoys togetherness, connectedness, belongingness, and commonness of place. However, a community is not always homogenous; it can also be heterogeneous (Burkey, 1993; Dorsner, 2004; Uemura, 1999).

In this context, participation means taking part in identifying needs and solving problems so as to improve the livelihoods of community members; it means initiating action, deciding, planning, deciding, and putting those plans into action to help people achieve the goals they set for themselves (Aikara, 2011). Zadeh and Ahmad (2010) have described participation as a vehicle of community development. The justification for participation is multifaceted: it promotes efficiency, accountability, and transparency; and it enhances ownership and empowerment, all of which are paramount to the alleviation of poverty (Dorsner, 2004).

CPA, therefore, can be defined as active involvement by people who share social, economic, political, and geographical dimensions, to transform or maintain their system. (Shepherd, 1998). CPA is about having the power to initiate innovations, take action, and drive a transformative agenda, thereby increasing the motivation, confidence, and self-esteem of community members in their effort to improve their lives. CPA enables better decisionmaking about, and sustainability of, projects or services because the community itself identifies its needs, initiates action, and manages its activities and resources. This also reduces costs, risks, and the likelihood of failure (Zadeh \& Ahmad, 2010). Stakeholders influence and guide development initiatives and can allocate resources efficiently and effectively (Uemura, 1999). The process of CPA empowers and leads proponents to take control of their lives and confront multiple issues that hinder their development. Furthermore, it strengthens and promotes cohesion in the community by increasing inclusion and connectedness, and by decreasing social isolation and division (City of Whitehorse, 2014). The result of this is that that problems are confronted together by people in the community (Pius, 2013). CPA deviates from the way research was conducted in the past by experts who came into the community to extract information, disappeared, and then used the information for purposes that were not directly beneficial to the community (Eruera, 2010). Today, community members become part of the research that seeks to uplift them from conditions of poverty and squalor (Hlalele, 2014). As Pius (2013) has correctly contended, "There can be no community development without community participation" (p. 587). 
In this study, community members, teachers, and learners worked together to work out how to inject meaningfulness into tourism education. These participants had the best view of the various strengths, resources, assets, skills, talents, and experiential knowledge of the community, all of which could be shared with the learners at school and beyond, to promote their survival and self-reliance. We used CPA as a vital link between theory and practice. Learners who struggled to understand the theoretical content of the subject found sanctuary in practical work and were motivated to learn by doing. This made education a democratic process, and, following Freire (1970) a tool of emancipation. In contrast, a teacher-centred approach uses education as a tool to preserve passiveness in the learners and domination in the teachers (Baker, 2011; Freire, 1970), because it is authority-driven (Petersen 2015). The epistemological stance of CPA affirms that knowledge is historically and socially located within cultural contexts, and that this means, inevitably, that there are different versions of reality, not just one objective reality (Graven \& Schafer, 2013; Lincoln \& Denzin, 2011; Mertens \& Yamashita, 2010).

\section{Research methodology}

This study sought to respond to the research question: How can we foster the implementation of an integrated tourism curriculum in Lesotho using a community participation approach?

To do so, we used qualitative participatory action research (PAR) in the employment of which, community members come together to solve their socioeconomic or other problems. In this case, community members were invited into the classroom to interact with the teachers and learners. Given the interactive nature of this research, it is important to understand the significance, value, and relevance of PAR. Its relevance is that it is people-centred and community-based and it is meant to transform lives, especially those of underprivileged people (Amaya \& Yeates, 2014; Le Grange, 2001; McTaggart, 1991; Mulligan, Wilkinson, Lusty, Dolome, \& Bong, 2015). The CPA described above was reinforced by our using PAR, because both approaches aim to transform lives, to emancipate people, and to empower them (Le Grange, 2001).

A qualitative research method allows the actual voices of the participants to be heard, thereby exposing perceptions and attitudes in a social context. This method captures the participants' lived experiences in complex, multiple realities (Check \& Schutt, 2012). We chose to use a qualitative method for this study because it allowed the participants to narrate their stories (McMillan \& Schumacher, 2010). This research method is also compatible with the semistructured interview technique, because this allowed the participants to explain their understandings, perceptions, and attitudes, as well as express the challenges they faced in life, and report on how they attempted to solve these. All this was done through opinion sharing, brainstorming, and discussion.

Data can be generated through a variety of methods and strategies using PAR. We generated data through free attitude interviews, participant observation, meetings, and workshops. Participant observation involves the recording of human behaviour in a social setting in 
which participants function (Munhall, 2003). It is a rich source of data often used in PAR, and includes seeing, hearing, and is structured to benefit and empower the participants' real life situation as it unfolds (Le Grande, 2009). Free attitude interviews offer freedom and flexibility to both the interviewer and the interviewees by allowing debate, discussions, and the expression of different points of view on an issue as they elaborate and expand on it, explore various related issues, and negotiate and construct meaning. Not only does the researcher ask questions, but she or he listens to the responses attentively, and is sensitive to the cultural norms and beliefs of the interviewees (Alshenqueeti, 2014). Meetings and workshops were also held to brainstorm suggestions, strategies, and activities that would assist in answering the research question.

We used content analysis to analyse the data generated. Content analysis is a non-invasive research technique that is used to make replicable and valid inferences by interpreting and coding textual material through examining patterns in communication (Krippendorff, 2019). The responses and conversations were transcribed verbatim, and then analysed and synthesised later to make meaning(s). This analysis generated specific themes that were used to structure the findings and the discussions.

\section{Site description and selection of participants}

The study was conducted at Phela High School (pseudonym) in a rural area at the foothills of Butha-Buthe District, north-eastern Lesotho. The school is situated along the road to Mahlasela Afri-Ski Resort, which attracts many tourists. The community around Phela High School lives in poverty and depends on subsistence farming to survive.

Participants in this study included four teachers, five community members, and ten learners. One of the authors of this article worked at the school as a geography teacher. We learned that the teachers helped each other to understand the theory of an integrated curriculum by co-planning and co-teaching topics/themes, and by monitoring how community members taught and trained learners to make craft products from grass, wood, and clay. Five parents were selected as participants because of their varying skills and expertise related to tourism. One parent could make craft products from grass/straw, another from wood, and another from clay. One owned and managed a lodge, and one was the chief executive officer (CEO) of the Ministry of Tourism, Environment and Culture. After the learners were trained to make the craft objects, the lodge owner provided space for them to sell these. The CEO shared information on the national vision of the economic contribution of travel and tourism and how the community could start community-based entrepreneurial tourism ventures. The ten Grade 9 learners were purposively selected because they lived within a radius of three kilometres of the school, and could, therefore, attend research sessions with ease. They were also told that they could withdraw from participation in the research without providing any reasons. However, where possible, the researcher, following Silverman (2013) asked them to give him a chance to intervene and try to solve disputes should this be necessary. The University of the Free State (UFS-HSD, 2017/0899) granted the ethical clearance to conduct the research. Anonymity was assured by withholding the co-researchers' names, and 
confidentiality was ensured by using pseudonyms. Co-researchers were respected and protected and were not compelled to participate or answer interview questions.

\section{Findings and discussions}

In this section, we present the findings and discuss the data in terms of the themes that emerged from the participants' responses and that were supported by the literature. These were knowledge of tourism as a vocational subject, resources, and collaboration.

\section{Knowledge of tourism as a vocational subject}

In Lesotho, tourism enjoys the same status as geography, history, and development studies, because, like these subjects, it was initially perceived as an academic subject and not a vocational one. Dube (2014) has asserted that tourism suffers from low status in South Africa because it is not considered a subject for university entrance, as mentioned above. However in Lesotho this is not the case; tourism is one of the subjects learners can elect for university entrance so its status is high. Therefore, relevant training should also recognise the community's contribution through its resources, assets, and person power. This recognition is in agreement with the literature that suggests that capacity building is one of the key factors for successful and sustainable implementation of an integrated curriculum. At one of the initial meetings that were held about the challenges of teaching tourism, Ms Mona (a teacher) articulated this when she said,

It is true that one now understands this thing [integrated curriculum] and tourism education a little better. More workshops are needed so that we do what we understand well.

In the same meeting, Mr Sam (a teacher) explained that

before we had understood it [tourism] in a similar fashion to geography, history, and development studies, but now we can see and understand that it has a practical side that has to be fulfilled, that can help learners to make a living.

Dube (2014) suggested that thorough advocacy for tourism education and its benefits should be conducted, and the necessary information disseminated to schools by the education directorate. It should be clear from the onset that tourism is a vocational subject that is aimed at equipping learners with productive and entrepreneurial skills that will give them employment opportunities and lead them to self-reliance. Nkumane (2008) has argued that advocacy should involve community members. They should be informed about the new practical subject called tourism, and its value to the learners through the employment opportunities it provides while learners are still at school, and beyond. After all, strategies for the implementation of an integrated curriculum advocate for the development of closer links with the community with a view to capacitating community members to take control of their lives, and the lives of their school-going children, through better decision-making. The CEO 
of tourism emphasised this point during a workshop on ways the department could assist communities, by saying,

As a department, we struggle to have communities [understand] what tourism is exactly about and how they can also benefit in the process. So [these] kind[s] of workshops are necessary and will make an impact because [they are] linked to teaching and learning in schools.

Dube (2014) has claimed that advocacy for tourism has not been loud enough considering its benefits for economic growth and job opportunities. His thoughts echo those of Nkumane (2008), whose study in KwaZulu-Natal, South Africa, demonstrated that community members did not think tourism was for them because they had never been exposed to it. They thought tourism was for whites, as had been the case during the apartheid regime, and for wealthy and enlightened Blacks. Ejiofor, Ajake, Oba, and Okpara (2012) found that rural communities in Nigeria lacked exposure, and Lovrentjev (2015) found the same situation in Croatia.

\section{Resources}

A theme that emerged very strongly from the free attitude interviews, meetings, and workshops with teachers and parents was related directly to resources. The responses these participants provided touched on the availability of resources, what they identified that could be viewed as resources, and the proper educational use of such resources. The views of the teachers, as articulated by Mr Maduna, who was supported by Mrs Oko, highlighted the lack of resources.

When this subject was introduced, I felt discouraged because I saw that I did not have resources. My school is based in a rural context where the community is so poor that thinking of charging parents to fund the buying of resources is impossible.

When probed further on what they view as resources and who should supply them, they said,

Schools should always have a budget to have adequate resources [such as] relevant textbooks, maps, globes, compasses, a television, wall charts, computers, internet, and money put aside for excursions to tourist attractions, a library, and a hall. Not all schools have these resources or can afford these resources.

These responses demonstrated that teachers have limited understanding of what constitutes a resource in tourism. They do not yet understand the value of seeing communities as a resource that can be tapped into to enhance the teaching and learning of tourism. Recognition and involvement of community members as resources will help teachers to recognise the Indigenous knowledges, wisdom, lived experiences, talents, and skills of community members as resources (see Graven \& Schafer, 2013; Mahlomaholo, 2013). Members of the community can be brought into the classroom as a resource to show the learners how tourism could benefit them in a practical way. 
In addition to a lack of resources and a lack of access to them, not being aware of the resources available or how to use them also added to the complexity of the problem. Mrs Madibo (a crafter) lamented,

Our kids have not been showing interest in the kind of work that we are doing because it was not directly linked to what they are doing with the teachers. So, these meetings ... have helped [me] to realise how I can help share my knowledge and resources with the school.

Mr Maduna immediately interjected,

I was not aware how rich the environment is with resources that can enhance the teaching and learning of tourism in the classroom.

From this response, it was evident that the way the study is structured benefitted and empowered the participants, as is espoused by PAR (Le Grange, 2009). Involving community members in education strengthens teaching because learners benefit from the lived experiences of the community, and this makes learning meaningful and exciting (Aikara, 2011; Spaull, 2013).

\section{Collaboration}

One of the important attributes and requirements of an integrated curriculum aimed at enhancing self-reliance is collaboration among different stakeholders. This collaboration enables the sharing of knowledge, skills, and resources, which culminates in enhancing the quality of the learning experience (Brauer \& Ferguson, 2015). Participants seemed to attach different values to collaboration as a way of enhancing tourism education. Initially, a teacher understood collaboration to mean "working together with other teachers to teach different sections of tourism but in a loose manner", as explained by Mrs Oko in one of the free attitude interviews. This type of response was given after a workshop that addressed integrated tourism teaching that emphasised a more structured and meaningful collaboration between different teachers teaching tourism. Ms Mona added,

This collaborative way of teaching tourism requires one to talk and share with [one's] colleagues. It is amazing how much one learns from such interactions.

For Mr Maduna, collaboration also leads to resource sharing and exchange, as illustrated by his response.

I could not imagine where all these resources that were needed to make the crafts would come from, but through the help and knowledge of the agricultural science teacher and the parents, my difficulties were resolved.

From these responses, it can be deduced that teachers benefitted from working with other teachers who, in turn, had other ideas and ways of tackling the content. This collaborating even resulted in access to resources that would not have been available had we been working 
in isolation. We also observed an improved sense of confidence in the teachers as they all warmed up to the idea of working together in a collaborative manner.

It was heart-warming to hear learners and parents in the group affirming the value of working with others, as evident from this response by Mpho (a learner), who said,

In the beginning we saw subject[s] as stand-alones but after this activity we now see that they are strongly linked, some knowledge from one subject can be used to make sense of aspects in the other subject. I learnt the different types of plants in agriculture and that helped to understand the type of grass suitable for crafting Basotho hats.

Mme Pone (a parent) commented,

I never thought that a person like me who never went to school could play such an important role in the teaching of learners. I thought my knowledge is not relevant and appreciated. I am just a poor woman trying to make a living with what I learnt from my parents, which is making wooden crafts.

From the comments above, we can see how the participants' understanding of, and the value they attached to, collaboration evolved to a point that was embraced by most participants. Inviting community members into the school setting added variation to teaching methods and approaches as Brauer and Ferguson (2015) have observed. Through interaction with community members and making crafts, learning became learner-centred and fun. The crafts were intended for sale to tourists and other customers by learners, thus generating income. Theory and practice were well integrated and balanced, and this brought joy to learning, as found by Graven and Schafer (2013) in a different context.

Collaboration holds mutual benefits as was expressed by the CEO of tourism in an interview. Working together with other schools allowed participants to

uplift their lives though the sales of crafts; to the schools through skills' transfer from community members to the learners; and to the tourism industry since it would employ capable learners with skills and knowledge.

Upliftment and improvement of life is in keeping with Lewin's (1944) PAR objective. The CEO expressed his belief that underprivileged people should not be at risk of socio-economic domination.

Working together in a collaborative way also changed the way learners viewed the parents. They came to respect them, understanding that even though parents were not formally educated they could play an important role in the economy of the country. Mpho stated,

I now know what my mother is going through in weaving the hats and the baskets. It is a tough job indeed [and] I respect her for that. 
This response seems to be in line with assertions by Ezeh and Ekemenzie (2015) and Raselimo and Mahao (2015) that when learners are exposed to new knowledge and skills for solving life challenges caused by poverty and unemployment, their attitudes to manual work become more positive, and they become productive and entrepreneurial.

\section{Conclusion}

How can we foster an integrated tourism curriculum in Lesotho using a Community Participation approach?

In this paper, we explored ways of fostering an integrated tourism curriculum in Lesotho using CPA, operationalised by PAR. One of the principles of CPA and PAR is that the endeavour of satisfying the needs of the community should be community-driven. By identifying their problems, and planning and deciding jointly how to solve those, community members are valued and respected. In our study we explored ways of improving how integrated tourism education could be implemented meaningfully by helping underprivileged learners in a single community. Community members transferred their knowledge and skills to learners since they wanted to help their children acquire entrepreneurship skills. The selfreliance project of making and selling crafts as a source of livelihood was a success, and there were signs that it will be sustainable, because it was a community-driven project. There is no doubt that the synergy and collaboration between the school and community members was emancipating and empowering to the school itself, to the teachers, and to the learners. The researchers and participants are convinced that improving the understanding of an integrated curriculum had been strengthened at the school that was involved in the study.

\section{References}

Aikara, J. (2011). Decentralisation of elementary education and community participation in Kerala. Rajagiri Journal of Social Development, 2(2), 161-194.

Akyeampong, A. K. (2002). Vocationalisation of secondary education in Ghana: A case study. Regional Vocational Skills Development Review, Human Development Region. Washington, DC: World Bank.

Alshenqueeti, H. (2014). Interviewing as a data collection method: Critical review. English Linguistics Research, 3(1), 1-7.

Amaya, A. B. \& Yeats, N. (2014). Participatory action research: New uses, new contexts, new challenges. PRARI Working Paper 15-6. Poverty Reduction and Regional Integration. Retrieved from https://www.open.ac.uk/socialsciences/prari/files/working_paper_6_en.pdf

Baker, C. R. (2011). A genealogical history of positivist and accounting research. Accounting History, 16, 207-221. 
Brauer, D. G., \& Ferguson, K. J. (2015). The integrated curriculum in medical education: AMEE Guide No. 96. Medical Teacher, 37, 312-322.

Burkey, M. (1993). People first: A guide to self-reliant participatory rural development. London, UK: Zed Books.

Check, J., \& Schutt, R. K. (2012). Research methods in education. London, UK: Sage.

Chere-Masopha, J. (2007). Education for all: Are we going the right way? Educational research paper presented at the BOLESWANA International Symposium in the context of EFA and MDGs. Roma, Lesotho.

City of Whitehorse. (2014). Volunteering and community participation strategy 2014-2017. Whitehorse, Australia. Retrieved from http://www.whitehorse.vic.gov.au/IgnitionSuite/uploads/docs/Draft\%20Whitehorse\% 20Volunteering\%20and\%20Community\%20Participation\%20Strategy\%2020142017.pdf

Daly, K., Brown, G. M., \& McGowan, C. L. (2012). Curriculum integration in the international baccalaureate middle years programme: Literature review. International Baccalaureate Organization. Retrieved from https://www.ibo.org/globalassets/publications/ibresearch/curriculumintegrationinthemypeng.pdf

Dorsner, C. (2004). Social exclusion and participation in community development projects: Evidence from Senegal. Social Policy and Administration, 38(4), 366-382.

Dube, Z. H. W. (2014). Conceptions and misconceptions of tourism as a school subject in the South African school curriculum. Alternations, 21(1), 153-170.

Ejiofor, A. T., Ajake, A. O., Oba, D. O., \& Okpara, D. E. (2012). Assessment of the influence of education on tourism development in Enugu, Nigeria. American Journal of American Research, 1(1), 33-42.

Eruera, M. (2010). Participatory action research groups: Community research engagement. MAI Review (special issue), 24(4), 95-105.

Ezeh, S. C., \& Ekemenzie, C. A. (2015). Evaluation of entrepreneurial skills needed by the students of universities for self-reliance and sustainable development in south east Nigeria. Journal of Emerging Trends in Educational Research and Policy Studies, 6(7), 236-243.

Freire, P. (1970). Pedagogy of the oppressed. New York, NY: Herder \& Herder.

Graven, M., \& Schafer, M. (2013). Interview with a mathematics doodler - Dr Sizwe Mabizela, Deputy VC, Rhodes University. Learning and Teaching Mathematics, 2013(14), 3-5. https://hdl.handle.net/10520/EJC142535 
Hlalele, D. (2014). Creating sustainable rural learning ecologies in South Africa: Realities, lessons and prospects. Journal of Human Ecologies, 45(2), 101-110.

Inglis, F., \& Aers, L. (2008). Key concepts in education. London, UK: Sage.

Krippendorff, K. (2019). Content analysis. An introduction to its methodology (4th ed.). London, UK: Sage.

Lake, K. (1994). Integrated curriculum. School Improvement Research Series. Office of Educational Research and Improvement (OERI), U.S. Department of Education. https://educationnorthwest.org/sites/default/files/integrated-curriculum.pdf

Le Grange, L. (2001). Challenges for participatory action research and indigenous knowledge in Africa. Acta Academica, 33(3), 136-150.

Le Grange, L. (2009). Participation and participatory action research (PAR) in environmental education processes: For what are people empowered? Australian Journal of Environmental Education, 25, 3-14.

Lewin, K. (1944). Dynamics of group action. Educational Leadership, 1(4), 195-200.

Lincoln, Y. S., \& Denzin, N. K. (2011). Toward a "refunctioned ethnography." In N. K. Denzin, \& Y. S. Lincoln (Eds.), The Sage handbook of qualitative research (4th ed.) (pp. 715-718). Thousand Oaks, CA: Sage.

Lovrentjev, S. (2015). Education of tourist guides in Croatia. Procedia Economics and Finance, 23, 555-562.

Mahlomaholo, M. G. (2010). A framework for university and provincial education departments' collaborative research towards the creation of sustainable empowering learning environments. In D. Francis, S. Mahlomaholo \& M. Nkoane (Eds). Praxis towards sustainable empowering learning environments in South Africa (pp. 1-26). Bloemfontein, RSA: Sun Press.

Mahlomaholo, S. M. G. (2013). Indigenous research and sustainable learning. International Journal of Education and Science, 5(3), 317-322.

Malik, A. S., \& Malik, R. H. (2011). Twelve tips for developing an integrated curriculum. Medical Teacher, 33, 99-104.

McMillan, J. H., \& Schumacher, S. (2010). Research in education. Evidence-based Inquiry (7th ed.). Cranbury, NJ: Pearson Education.

McTaggart, R. (1991). Principles of participatory action research. Adult Education Quarterly, 4(3), 168-187. 
Mertens, D., \& Yamashita, M. (2010). Mission statement for the American Evaluation Association's topical interest group: Mixed methods in evaluation. London, UK: Sage.

Ministry of Education and Training (MoET). (2009). Curriculum and assessment policy: Education for individual and social development. Maseru: Kingdom of Lesotho.

Mulligan, H., Wilkinson, A., Lusty, A., Dolome, A., \& Bong, S. (2015). Consumers and health professionals' perceptions of participatory action research in developing a health resource. New Zealand Journal of Physiotherapy, 43(93), 93-97.

Munhall, A. (2003). In the field: Notes on observation in qualitative research. Journal of Advanced Nursing, 4(3), 1-19.

Nkumane, B. M. (2008). Tourism education policy applications in the Zululand District, KwaZulu-Natal (Master's dissertation). University of Zululand, Empangeni, RSA. http://hdl.handle.net/10530/92

Omede, J. (2012). Proliferation of illegal tertiary institutions of learning in Nigeria: Implications for quality education, self-reliance, economic growth and development. Journal of Emerging Trends in Educational Research and Policy Studies, 3(3), 294298.

Park, M. (2008). Implementing curriculum integration: The experiences of Korean elementary teachers. Asia-Pacific Education Review, 8(3), 308-319.

Petersen, J. (2015). The development of tourism as a young school subject: A comparative curriculum analysis (Unpublished master's thesis). University of Cape Town, RSA. http://hdl.handle.net/11427/13774

Pius, K. J. (2013). An assessment of community participation in the sustainability of school feeding programme in primary schools: A case of Embakasi, Kenya. International Journal of Academic Research in Business and Social Sciences, 3(9), 584-595.

Raselimo, M., \& Mahao, M. (2015). The Lesotho curriculum and assessment policy: Opportunities and threats. South African Journal of Education, 35(1), 1-12.

Sarkodie, N. A., \& Adom, K. (2015). Bridging the gap between hospitality/tourism education and hospitality/tourism industry in Ghana. International Journal of Research in Humanities and Social Studies, 2(7), 114-120.

Shankar, P. R. (2014). Challenges in implementing an integrated curriculum. Xavier University School of Medicine Journal, 6(4), e74-e77.

Shepherd, A. (1998). Sustainable rural development. New York, NY: Palgrave.

Silverman, D. (2013). Doing qualitative research. London, UK: Sage. 
Spaull, N. (2013). South Africa's education crisis: The quality of education in South Africa 1994-2011. Johannesburg, RSA: Centre for Development and Enterprise.

Tsayang, G. T. (1998). Evaluation of school partnership policy in Botswana: A qualitative approach to six case studies. Lewiston, NY: Edwin Mellen.

Uemura, M. (1999). Community participation in education: What do we know? Washington, DC: World Bank.

Zadeh, B. S., \& Ahmad, N. (2010). Participation and community development. Current Research Journal of Social Sciences, 2(1), 13-14. 